\title{
Characterization of olivine-supported nickel silicate as potential catalysts for tar removal from biomass gasification
}

Zhongkui Zhao ${ }^{1}$, Nandita Lakshminarayanan ${ }^{1}$, Scott L. Swartz ${ }^{2}$, Gene B. Arkenberg $^{2}$, Larry G. Felix ${ }^{3}$, Rachid B. Slimane ${ }^{4}$, Chun C. Choi ${ }^{4}$, Umit S. Ozkan ${ }^{1, *}$

${ }^{1}$ Department of Chemical and Biomolecular Engineering, The Ohio State University, 140 W. 19th Avenue, Columbus, OH 43210, USA

${ }^{2}$ NexTech Materials, Ltd., 404 Enterprise Drive, Lewis Center, OH 43035, USA

3 Gas Technology Institute, 1500 First Avenue, North, Suite L134, Birmingham, AL, 35203-1821, USA

4 Gas Technology Institute, 1700 South Mt. Prospect Rd. Des Plaines, IL, 60618-1804, USA

* To whom correspondence should be addressed.

E-mail: Ozkan.1@osu.edu

Phone: 614-292-6623

Fax: 614-292-3769 


\section{Abstract}

In this work olivine-supported nickel silicate, which was prepared by thermal impregnation is considered as a potential tar removal catalyst for cleaning the gas stream during biomass gasification. Previous work on Ni-olivine catalysts has shown that these catalysts have good activity for the tar-reforming reaction as well as good stability and tolerance to coking. In this work, various characterization techniques such as X-ray diffraction, X-ray photoelectron spectroscopy, laser Raman spectroscopy, temperature programmed reduction, temperature programmed reaction, and subsequent temperature programmed oxidation are employed to reveal the properties of the catalyst surface and bulk as well as their relationship to catalytic activity. Higher thermal impregnation temperatures produce stronger interactions between the active component and support, leading to better coke tolerance. Relative amounts of reducible $\mathrm{Ni}$, Fe species and surface $\mathrm{Mg}$ have an influence on catalytic behavior. Moreover, compared to olivine, the $\mathrm{Ni}_{2} \mathrm{SiO}_{4} /$ olivine catalyst exhibits good catalytic activity for dry reforming, water gas shift, reverse water gas shift and methanation reactions, as well as the steam reforming reaction.

Keywords: Olivine; Nickel silicate; Thermal impregnation; Steam reforming; Tar removal; Biomass gasification 


\section{Introduction}

With the constant rise in petroleum prices, the use of biomass as a potential and promising renewable energy resource, partially replacing fossil fuels via biomass-to-liquid or biomass-to-gas processes has been receiving increasing interest [1]. Biomass gasification is currently a leading option for converting biomass to fuel or chemicals since many of the syngas utilization technologies have already been proven [2]. However, one of the most crucial technical barriers is the effective removal of the tar produced. Tar is a mixture of condensable aromatic compounds [3-5]. The higher molecular weight products of biomass gasification are collectively called tar and are known to be refractory and difficult to remove by thermal, catalytic or physical processes. Tar can also cause problems downstream in the processing clogging coolers, filters and suction channels [6]. Thus, tar removal is one of the major technological barriers to gasification technology. Several technologies are proven for the removal of tar [7-9], and catalytic tar conversion is a technically and economically interesting approach for gas cleaning [10-12].

$\mathrm{Ni}$ based catalysts [13-21] have been proved to be effective for eliminating tar from biomass gasification gas due to their high tar cracking activity, along with the additional advantages of steam reforming and water gas shift activity, which allows adjustment of the ratio of $\mathrm{H}_{2}$ to $\mathrm{CO}$ in the product gas. However, there are two main limitations for $\mathrm{Ni}$ based catalysts: attrition and 
rapid deactivation by coke formation and sintering [22-27]. Olivine is a naturally occurring mineral with the general formula $(\mathrm{Mg}, \mathrm{Fe})_{2} \mathrm{SiO}_{4}$. Olivine is mechanically hard and attrition resistant, and thus been identified as a potential support material for nickel based reforming catalysts used in fluidized bed gasification processes [28-36].

In our previous work, the thermal impregnation technique has been developed to prepare the robust and coke-resistant olivine-supported nickel catalyst for tar removal [32-34]. In the present paper, a conventional ceramic processing route was employed, by using commercially available equipment and methods for preparing large quantities of the catalyst. Methane steam reforming is used as a model reaction. Various characterization techniques, such as X-ray diffraction (XRD), X-ray Photoelectron Spectroscopy (XPS), BET, Temperature-programmed reduction (TPR), Laser Raman Spectroscopy (LRS) have been used to study the catalyst surface and structural characteristics. Temperature programmed reaction experiments of methane steam reforming were performed to investigate the relative activity. Effect of calcination temperature and olivine geographical locations on catalyst nature and properties are also examined. Besides steam reforming, $\mathrm{CO}_{2}$ dry reforming and water gas shift reaction are also examined since they are important in determining the ratio of $\mathrm{H}_{2} / \mathrm{CO}$, for the downstream utilization of biomass gasification gas. 


\section{Experimental}

\subsection{Catalyst preparation}

A previously developed thermal impregnation technique [35] was used to prepare $\mathrm{Ni}_{2} \mathrm{SiO}_{4}\left(\mathrm{SiO}_{2}\right.$ and $\mathrm{NiO}$ as precursors $)$ and the olivine supported $\mathrm{Ni}_{2} \mathrm{SiO}_{4}$ catalysts (the synthesized $\mathrm{Ni}_{2} \mathrm{SiO}_{4}$ and the natural olivines as precursors). The difference is that the precursors were attrition milled for four hours with zirconia in isopropyl alcohol as the milling fluid, and then dried to a powder for initial mixing before calcination. The $\mathrm{Ni}_{2} \mathrm{SiO}_{4}$ was supported on olivine samples from different geographical locations and the high temperature calcination was conducted at either $1100^{\circ} \mathrm{C}$ or $1300^{\circ} \mathrm{C}$.

\subsection{Catalyst characterization}

Surface area analysis (BET) was performed over both fresh and spent olivine and $\mathrm{Ni}$-doped olivine samples by $\mathrm{Kr}$ adsorption at $77 \mathrm{~K}$ using a Micromeritics ASAP 2010 instrument. $\mathrm{Kr}$ was selected as the adsorbate molecule because of the low surface area of the samples $\left(<5 \mathrm{~m}^{2} / \mathrm{g}\right)$. Before measurement, the samples were degassed under vacuum at $130^{\circ} \mathrm{C}$ overnight.

The X-ray diffraction (XRD) patterns were obtained using a Bruker D8 Advance diffractometer with a Braun position sensitive $\left(8^{\circ}\right)$ detector. The spectra were obtained between $2-\theta$ values of 20 and $45^{\circ}$ using $\mathrm{Cu} \mathrm{K}_{\alpha 1}$ 
radiation $(1.5406 \mathrm{~nm})$ at $40 \mathrm{kV}$ and $50 \mathrm{~mA}$. Other experimental parameters were as follows: $0.014367^{\circ}$ step size, 0.5 second step time, $1^{\circ}$ divergence slit, $0.5^{\circ}$ anti-scatter slit, and $0.75^{\prime \prime}$ detector width. The data were acquired with a 9-sample holder attachment using rotating polypropylene sample holders. Phase identification was done using The International Center for Diffraction Data (ICDD) library.

Laser Raman spectra (LRS) were collected on powdered samples under ambient conditions using a Horiba Jobin-Yvon LabRam HR800 spectrometer with a $633 \mathrm{~nm}$ helium-neon laser as the excitation source.

The surface characterization of the samples by X-ray Photoelectron Spectroscopy (XPS) was done with a Kratos Ultra Axis Spectrometer under high vacuum using a monochromatic Al source at $13 \mathrm{kV}$ and $10 \mathrm{~mA}$. The source was used in conjunction with analyzer mode, hybrid lens mode, and a slot aperture setting. The samples were ground into carbon tape and degassed first before being loaded into the analysis chamber. The height optimization for maximum signal was done by using the $C$ 1s peak at 284.5 $\mathrm{eV}$ for correction. The charge neutralizer was set to a current of 2.1 A, bias of $1.3 \mathrm{~V}$ and a charge of $2.3 \mathrm{~V}$. Each region was scanned 4 times. The deconvolution was performed using XPS Peak 4.1 program. Elemental surface composition was calculated using transmission values and relative sensitivity factors specific for the instrument equipped with an Al source.

The temperature programmed reduction (TPR) experiments were 
performed with AutoChem II 2920 using a quartz U-shape tube with $100 \mathrm{mg}$ of sample. A pretreatment $\left(30 \mathrm{~mL} / \mathrm{min} \mathrm{He}\right.$ flow with hold at $900{ }^{\circ} \mathrm{C}$ for $\left.10 \mathrm{~min}\right)$ was first performed. TPR was conducted with the reductive gas mixture (3 $\mathrm{mL} / \mathrm{min}$ of $\mathrm{H}_{2}$ and $27 \mathrm{~mL} / \mathrm{min} \mathrm{Ar}$ ) flowing to the reactor as it was heated at a ramp rate of $15^{\circ} \mathrm{C} / \mathrm{min}$ from ambient to $950^{\circ} \mathrm{C}$, where it was held for $30 \mathrm{~min}$. The TCD was used for quantitative determination of $\mathrm{H}_{2}$ consumption and was calibrated using standards.

Temperature programmed reaction (TPRxn) experiments with $\mathrm{CH}_{4}$ and $\mathrm{H}_{2} \mathrm{O}$ (steam reforming of methane) were performed on an equal mass basis (100 mg) in a quartz U-tube reactor for the initial activity evaluation. The temperature was measured using K-type thermocouples. The effluent was monitored with a Cirrus RGA mass spectrometer using a Faraday detector. Before performing TPRxn, the reduction pretreatment was carried out. Pretreatment conditions were as follows: $20 \% \mathrm{H}_{2} / \mathrm{He}, 30 \mathrm{~mL} / \mathrm{min}$ of total flow rate, ramped at the rate of $20^{\circ} \mathrm{C} / \mathrm{min}$ to $900^{\circ} \mathrm{C}$, and held for $30 \mathrm{~min}$. After the pretreatment, the samples were cooled to ambient temperature in $\mathrm{He}$ and then $50 \mathrm{~mL} / \mathrm{min}$ of the reactant mixture $\left(2 \% \mathrm{CH}_{4}\right.$ and $2 \% \mathrm{H}_{2} \mathrm{O}$, He balance $)$ was introduced to the reactor. The temperature was increased from ambient temperature to $900^{\circ} \mathrm{C}$ at a ramp rate of $20^{\circ} \mathrm{C} / \mathrm{min}$, and then held constant for 30 min. Following the TPRxn experiment, the flow was switched to He and the samples were cooled to ambient temperature in He atmosphere. Then temperature programmed oxidation (TPO) experiments were performed to 
study coking characteristics. The $\mathrm{CO}_{2}(\mathrm{~m} / \mathrm{z}$ 44) signal was used to characterize the relative amount of deposited coke. TPO experiment conditions were as follows: $6 \% \mathrm{O}_{2} / \mathrm{He}, 30 \mathrm{~mL} / \mathrm{min}$, ramp rate of $20^{\circ} \mathrm{C} / \mathrm{min}$ to $900^{\circ} \mathrm{C}$, and held for $15 \mathrm{~min}$.

Experiments to probe the reaction network were performed with conditions similar to the TPRxn experiments. The samples $\left(\mathrm{Ni}_{2} \mathrm{SiO}_{4} /\right.$ olivine, olivine without nickel silicate was also included for comparison) were pre-reduced by using the same conditions as above. Based on the components of the simulated syngas, possible reactions including the Boudouard reaction $(10 \% \mathrm{CO} / \mathrm{He})$, methanation $\left(10 \% \mathrm{CO}\right.$ and $20 \% \mathrm{H}_{2}, \mathrm{He}$ balance), $\mathrm{CO}_{2}$ methanation ( $15 \% \mathrm{CO}_{2}$ and $20 \% \mathrm{H}_{2} / \mathrm{He}$ ), water gas shift reaction ( $5 \% \mathrm{CO}$ and $5 \% \mathrm{H}_{2} \mathrm{O}$, He balance), reverse WGS $\left(15 \% \mathrm{CO}_{2}\right.$ and $\left.20 \% \mathrm{H}_{2} / \mathrm{He}\right), \mathrm{CO}_{2}$ dry reforming $\left(15 \% \mathrm{CO}_{2}\right.$ and $5 \% \mathrm{CH}_{4}$, He balance) and $\mathrm{CH}_{4}$ decomposition $\left(5 \% \mathrm{CH}_{4} / \mathrm{He}\right)$ reactions were investigated. The temperature program was a ramp rate of $10{ }^{\circ} \mathrm{C} / \mathrm{min}$ to $900^{\circ} \mathrm{C}$ and a hold time of $15 \mathrm{~min}$. In all cases, the $50 \mathrm{~mL} / \mathrm{min}$ total flow rate of mixture gas was used.

\section{Results and Discussion}

The olivine supported nickel silicate catalysts synthesized by thermal-impregnation technique were studied in detail. Various characterization techniques were employed to study the nature of the catalyst and the relationship between catalyst structure and properties. In order to 
compare catalytic activity, the temperature-programmed steam reforming of methane is used as a model reaction. The catalysts are compared based on their calcination temperature as well as the geographical location of the olivine support.

\subsection{Comparison of olivine, bulk $\mathrm{Ni}_{2} \mathrm{SiO}_{4}$ and olivine-supported $\mathrm{Ni}_{2} \mathrm{SiO}_{4}$}

In this section, the structure, nature and catalytic properties of the olivine with and without nickel silicate are discussed. Unsupported nickel silicate was also included for comparison. The olivine used is from Norway until indicated otherwise.

Due to low surface areas of the catalysts, BET experiments were done using $\mathrm{Kr}$ as the adsorption molecule. The surface area for $\mathrm{Ni}_{2} \mathrm{SiO}_{4}$, olivine and $\mathrm{Ni}_{2} \mathrm{SiO}_{4}$ /olivine are $0.7,0.1$ and $2.0 \mathrm{~m}^{2} \cdot \mathrm{g}^{-1}$ respectively. Figure 1 presents the X-ray diffraction patterns for the three samples. The pattern for $\mathrm{Ni}_{2} \mathrm{SiO}_{4}$ is also included for comparison. The patterns have been offset for clarity. The olivine sample pattern matches well with the olivine crystal phase and the miller indices labeled correspond to that of $\mathrm{Mg}_{2} \mathrm{SiO}_{4}$ (ICDD file \# 80-944). When $\mathrm{Ni}_{2} \mathrm{SiO}_{4}$ is impregnated onto the olivine, the peaks corresponding to the olivine and $\mathrm{Ni}_{2} \mathrm{SiO}_{4}$ (ICDD file \# 3-780) phases may be observed. Traces of impurity phases such as $\gamma-\mathrm{Fe}_{2} \mathrm{O}_{3}$ (ICDD file \#73-2234), $\mathrm{Fe}_{3} \mathrm{O}_{4}$ (ICDD file \#65-3107), and $\mathrm{MgFe}_{2} \mathrm{O}_{4}$ (ICDD file \#88-1936) may also present. These phases have overlapping peaks and are difficult to distinguish. 
Laser Raman spectra were obtained between 100 and $1000 \mathrm{~cm}^{-1}$ on the samples exposed to air at ambient temperature. Figure 2 compares the LRS for olivine, nickel silicate and the synthetic catalyst containing $40 \mathrm{wt} \%$ of $\mathrm{Ni}_{2} \mathrm{SiO}_{4}$ and $60 \mathrm{wt} \%$ of Norwegian olivine. The bands in the region between $400-750 \mathrm{~cm}^{-1}$ has been attributed to internal bending vibrational modes of the ionic group [34]. Bands at 822 and $841 \mathrm{~cm}^{-1}$ are attributed to the lattice modes of $\mathrm{Ni}_{2} \mathrm{SiO}_{4}$ [35]. For $\mathrm{Ni}_{2} \mathrm{SiO}_{4} /$ olivine, the $\mathrm{Mg}_{2} \mathrm{SiO}_{4}, \mathrm{Fe}_{2} \mathrm{SiO}_{4}$ and $\mathrm{Ni}_{2} \mathrm{SiO}_{4}$ bands are observed, although there are small changes in the Raman shifts for some peak positions and peak intensity. The peaks shift may be attributed to the interaction of olivine and nickel silicate as a result of the high temperature calcination.

Temperature programmed reduction (TPR) experiments were performed on olivine samples with and without $\mathrm{Ni}_{2} \mathrm{SiO}_{4}$. The samples are compared on an equal mass of $\mathrm{Ni}_{2} \mathrm{SiO}_{4}$ basis (100mg of $\mathrm{Ni}_{2} \mathrm{SiO}_{4} /$ olivine, $40 \mathrm{mg}$ of $\mathrm{Ni}_{2} \mathrm{SiO}_{4}$ ). TPR profile of olivine is also included as a blank. Figure 3 presents the TPR profiles for the three samples. There is no $\mathrm{H}_{2}$ consumption over olivine, which is due to the absence of reducible iron species on the surface of olivine mineral [9]. For $\mathrm{Ni}_{2} \mathrm{SiO}_{4}$ and $\mathrm{Ni}_{2} \mathrm{SiO}_{4} /$ olivine samples, two kinds of reducible $\mathrm{Ni}$ species appear to exist. The first reduction peak may correspond to $\mathrm{NiO}$ while the other may be attributed to $\mathrm{Ni}_{2} \mathrm{SiO}_{4}$. The reduction temperature corresponding to the first peak shifts towards a higher temperature over the supported catalyst, which suggests interaction between the support and $\mathrm{Ni}_{2} \mathrm{SiO}_{4}$ during the high-temperature calcination.

Methane steam reforming TPRxn experiments were performed on the bare-support, unsupported $\mathrm{Ni}_{2} \mathrm{SiO}_{4}$ and the combined catalyst, $\mathrm{Ni}_{2} \mathrm{SiO}_{4}$ /olivine. The results are shown in Figure 4. No measurable activity was observed over 
the bare olivine support. The reaction on $\mathrm{Ni}_{2} \mathrm{SiO}_{4}$ started at lower temperatures than on the supported catalyst. A similar trend was seen in the TPR results which showed pure $\mathrm{Ni}_{2} \mathrm{SiO}_{4}$ to start reducing at lower temperatures. This ease of reducibility may account for the lower take-off temperature. It is also possible that the supported catalyst may have bi-metallic silicates such as $\mathrm{Ni}-\mathrm{Mg}-\mathrm{SiO}_{4}$ which may need higher temperatures to be activated.

\subsection{Effect of preparation temperature}

High temperature calcination promotes interaction between active component and support, which has been reported to improve the coke tolerance [33]. However there is an optimum temperature as very high calcination temperatures could lead to deactivation of the active phase and sintering. In this section, effects of preparation temperature on catalyst nature and catalytic properties were studied. $\mathrm{Ni}_{2} \mathrm{SiO}_{4} /$ olivine catalysts were prepared at two different temperatures (TI-1100 and TI-1300, thermal impregnation at $1100{ }^{\circ} \mathrm{C}$ and $1300^{\circ} \mathrm{C}$, respectively) for characterization.

Figure 5 presents XRD patterns of TI-1100 and TI-1300 olivine supported $\mathrm{Ni}_{2} \mathrm{SiO}_{4}$ catalysts. From XRD patterns it is seen that increasing calcination temperature does not lead to any significant change in crystalline phases. But the peaks for $\mathrm{Tl}-1300$ are much sharper than those of $\mathrm{Tl}-100$ implying larger crystalline size due to sintering. The BET measurement results show that the surface area decreases from 2.0 to $0.2 \mathrm{~m}^{2} \cdot \mathrm{g}^{-1}$ if calcination temperature is increased from $1100^{\circ} \mathrm{C}$ to $1300^{\circ} \mathrm{C}$. 
Figure 6 presents the Raman spectra of the olivine with $\mathrm{Ni}_{2} \mathrm{SiO}_{4}$ calcined at $1100^{\circ} \mathrm{C}$ and $1300^{\circ} \mathrm{C}$ respectively. Except for slight peak broadening, no major differences were observed between the two samples.

Figure 7, where TPR profiles are presented, shows significant changes in the reducibility of the catalyst. A higher calcination temperature appears to lead to a decrease in the amount of reducible species.

XPS studies were performed on $\mathrm{TI}-1100$ and $\mathrm{TI}-1300$, and the individual regions for $\mathrm{Fe}, \mathrm{Mg}, \mathrm{Ni}$ and $\mathrm{SI}$ are presented as Figure 8. No trace elements (e.g. $\mathrm{Mn}, \mathrm{Cr}, \mathrm{Al}$, etc.) were detected on the sample surface. From XPS results, on the both samples, Fe (724.8 eV for Fe $2 p_{1 / 2}$ and $711.1 \mathrm{eV}$ for $\left.\mathrm{Fe} 2 p_{3 / 2}\right), \mathrm{Ni}$ (873.8 $\mathrm{eV}$ for $\mathrm{Ni} 2 p_{1 / 2}$ and $856.1 \mathrm{eV}$ for $\left.\mathrm{Ni} 2 p_{3 / 2}\right), \mathrm{Mg}(50.1 \mathrm{eV}$ for $\mathrm{Mg} 2 p)$ and Si $(101.9 \mathrm{eV}$ for Si $2 p)$ species were detected. The major difference was observed in the Fe $2 p$ spectra, which showed a decrease in the amount of surface Fe species for the sample calcined at the higher temperature.

Table 1 gives the $\mathrm{Fe}, \mathrm{Ni}, \mathrm{Mg}$ and $\mathrm{Si}$ relative amounts calculated using area ratio of the amount of these elements to the total area of the four surface species. From the data, the amounts of $\mathrm{Ni}$ and $\mathrm{Fe}$ on the both samples are similar, but much more surface Mg species present on TI-1300 sample.

The effect of calcination temperature on the TPRxn is examined, and the reaction results are presented in Figures 9. The reaction began at similar temperatures, but a higher calcination temperature led to decreased catalytic activity at $900^{\circ} \mathrm{C}$. Near $800^{\circ} \mathrm{C}$, methane was nearly completely converted on 
the catalyst calcined at $1100{ }^{\circ} \mathrm{C}$. A significant amount of unreacted methane still existed at $900^{\circ} \mathrm{C}$ for the sample calcined at $1300{ }^{\circ} \mathrm{C}$. The higher temperature calcination leads to larger crystalline size, larger amount of surface Mg species and the lower amount of reducible species, which may lead to lower catalytic activity on $\mathrm{TI}-1300$. Figure $9 \mathrm{c}$, presents the results from TPO following the TPRxn experiments. There is significantly greater coking over the $\mathrm{TI}-1100$ catalyst. Thus higher preparation temperatures can produce robust and strong coke tolerant catalyst [37, 38].

\subsection{Effect of olivine geographical location}

Olivine minerals obtained from different geographical locations have different element weight percentage. The Norwegian olivine (elemental analysis was performed using the ASTM D-6349 ICP analysis procedure, $28.81 \%, 20.38 \%, 5.04 \%, 0.2 \%, 0.24 \%, 0.21 \%$ and $0.18 \%$ for $\mathrm{Mg}, \mathrm{Si}, \mathrm{Fe}, \mathrm{Ni}$, $\mathrm{Al}, \mathrm{Cr}$ and $\mathrm{Ca}$ respectively) and domestic olivine from North Carolina State (30.68\%, 19.35\%, 5.68\%, 0.21\%, 0.19\%, 0.28\%, 0.1\%, $0.09 \%$ and $0.01 \%$ for $\mathrm{Mg}, \mathrm{Si}, \mathrm{Fe}, \mathrm{Ni}, \mathrm{Al}, \mathrm{Cr}, \mathrm{Ca}, \mathrm{Mn}$ and $\mathrm{Zn}$ respectively) were used to produce olivine supported nickel silicate catalysts, which are named as $\mathrm{Ni}_{2} \mathrm{SiO}_{4} / \mathrm{NOR}$ and $\mathrm{Ni}_{2} \mathrm{SiO}_{4} / \mathrm{NC}$ respectively.

Figure 10 presents XRD patterns of $\mathrm{Ni}_{2} \mathrm{SiO}_{4} / \mathrm{NOR}$ and $\mathrm{Ni}_{2} \mathrm{SiO}_{4} / \mathrm{NC}$ olivine supported $\mathrm{Ni}_{2} \mathrm{SiO}_{4}$ catalysts. From the XRD patterns, sharper diffraction peaks for $\mathrm{Ni}_{2} \mathrm{SiO}_{4} / \mathrm{NC}$ than $\mathrm{Ni}_{2} \mathrm{SiO}_{4} / \mathrm{NOR}$ can be observed, which indicates smaller crystalline size in $\mathrm{Ni}_{2} \mathrm{SiO}_{4} / \mathrm{NOR}$ than $\mathrm{Ni}_{2} \mathrm{SiO}_{4} / \mathrm{NC}$. No obvious 
differences in crystalline phases are observed. The BET surface areas were 2.0 and $6.9 \mathrm{~m}^{2} \cdot \mathrm{g}^{-1}$ for $\mathrm{Ni}_{2} \mathrm{SiO}_{4} / \mathrm{NOR}$ and $\mathrm{Ni}_{2} \mathrm{SiO}_{4} / \mathrm{NC}$ respectively.

Raman spectra were also collected on $\mathrm{Ni}_{2} \mathrm{SiO}_{4}$ doped catalysts and the results are presented in Figure 11. Similar spectra on the both samples were obtained. There is a slight difference in the internal bending vibrational modes of the $\mathrm{SiO}_{4}$ ionic group as indicated by the band at $605 \mathrm{~cm}^{-1}$.

The effect of the support on TPR behavior was also compared as shown in Figure 12. While the profiles appeared similar, the relative area ratio between the high and low temperature peaks was different. The reduction temperature for the low temperature feature on $\mathrm{Ni}_{2} \mathrm{SiO}_{4} / \mathrm{NC}$ catalyst was lower than on $\mathrm{Ni}_{2} \mathrm{SiO}_{4} / \mathrm{NOR}$, which allows activity to begin at a lower temperature. However, the $\mathrm{H}_{2}$ consumption for the high-temperature feature on $\mathrm{Ni}_{2} \mathrm{SiO}_{4} / \mathrm{NOR}$ was slightly larger than on the $\mathrm{Ni}_{2} \mathrm{SiO}_{4} / \mathrm{NC}$ and could imply better activity and stability at high temperatures.

XPS experiments were performed on $\mathrm{Ni}_{2} \mathrm{SiO} 4 / \mathrm{NOR}$ and $\mathrm{Ni}_{2} \mathrm{SiO} 4 / \mathrm{NC}$, and the individual regions are presented as Figure 13. On both samples, Fe (724.8 eV for Fe 2p1/2 and 711.1 eV for Fe 2p3/2), Ni (873.8 eV for Ni 2p1/2 and 856.1 eV for Ni 2p3/2), Mg (50.1 eV for Mg 2p) and Si (101.9 eV for Si 2p) species were detected, but no obvious differences could be observed. Quantitative analysis was further done on the XPS data of the two samples. Table 2 presents the relative amounts of $\mathrm{Fe}, \mathrm{Ni}, \mathrm{Mg}$ and $\mathrm{Si}$ calculated by area ratio to total area of the four main surface species. From the results, the 
relative amounts of surface $\mathrm{Fe}$ and $\mathrm{Ni}$ on $\mathrm{Ni}_{2} \mathrm{SiO}_{4} / \mathrm{NOR}$ are much higher than on $\mathrm{Ni}_{2} \mathrm{SiO} / \mathrm{NC}$, and also the amount of surface $\mathrm{Mg}$ on $\mathrm{Ni}_{2} \mathrm{SiO}_{4} / \mathrm{NOR}$ is lower than that on $\mathrm{Ni}_{2} \mathrm{SiO}_{4} / \mathrm{NC}$.

Methane steam reforming experiments were performed on both $\mathrm{Ni}_{2} \mathrm{SiO} 4 / \mathrm{NOR}$ and $\mathrm{Ni}_{2} \mathrm{SiO} 4 / \mathrm{NC}$ catalysts as a screening reaction to study activity. TPO experiments were performed after TPRxn experiments to evaluate coke tolerance. Figure $14 \mathrm{a}$ and $\mathrm{b}$ present the TPrxn profiles for methane and hydrogen signal, respectively. Figure $14 \mathrm{c}$ shows the $\mathrm{CO}_{2}$ signal from the TPO experiment performed following the reaction. The $\mathrm{Ni}_{2} \mathrm{SiO} 4 / \mathrm{NC}$ catalyst demonstrated higher activity, consistent with TPR data, with the reaction starting at a lower temperature. Thus, the position of the first reduction peak is related to the take-off temperature of the reaction. Although the surface area of $\mathrm{Ni}_{2} \mathrm{SiO} / \mathrm{NC}$ catalyst is three times higher than $\mathrm{Ni}_{2} \mathrm{SiO}_{4} / \mathrm{NOR}$, lower catalytic activity on $\mathrm{Ni}_{2} \mathrm{SiO}_{4} / \mathrm{NC}$ is observed, which shows that the difference in surface area have no obvious influence on catalytic properties. From the TPO results it is seen the support showed an significant effect upon the coke resistance, with the $\mathrm{Ni}_{2} \mathrm{SiO}_{4} / \mathrm{NOR}$ catalyst possessing higher resistance to coke formation.

3.4 Experiments to probe the possible reactions in simulated biomass gasification

The typical biomass gasification gas is composed of $10.0 \% \mathrm{CO}, 15 \% \mathrm{CO}_{2}$, 
$20 \% \mathrm{H}_{2}, 5 \% \mathrm{CH}_{4}$ and $20 \% \mathrm{H}_{2} \mathrm{O}$ respectively. In addition to steam reforming, there are other relevant reactions that can take place in biomass gasification, such as Boudouard reaction, methanation, water gas shift (WGS), reverse WGS, $\mathrm{CO}_{2}$ dry reforming, methane decomposition etc. This section presents the TPrxn results from these reactions performed over $\mathrm{Ni}_{2} \mathrm{SiO}_{4}$ supported on olivine and bare olivine. Neither supported $\mathrm{Ni}_{2} \mathrm{SiO}_{4}$ nor the bare olivine showed any CO Boudouard and methane decomposition activity.

Figures 15 and 16 present the TPRxn reaction results over $\mathrm{Ni}_{2} \mathrm{SiO}_{4} /$ olivine and olivine respectively, and the profiles are offset for clarity.

$\mathrm{Ni}_{2} \mathrm{SiO}_{4} /$ olivine shows significant activity for dry reforming (Fig 15 a) and water gas shift reaction, both forward and reverse (Fig 15b and d). Methanation is observed over the $\mathrm{Ni}_{2} \mathrm{SiO}_{4}$ catalyst (Figure $15 \mathrm{c}$ ) over the thermodynamically permitted temperature window. The bare olivine support shows some activity for the water gas shift and reverse water gas shift (Figure $16 \mathrm{~b}$ and $\mathrm{d}$ ), but negligible activity for dry reforming and methanation reactions.

Based on TPRxn experiment results, thermal impregnation method prepared Norwegian olivine supported nickel silicate shows promising catalytic activity. The relevant aspects of catalytic tar elimination behaviors such as catalyst aging behavior and catalyst activity in biomass gasification process need to be further studied.

\section{Conclusion}


Nickel silicate catalysts supported on Norwegian olivine prepared by thermal impregnation shows promising activity for steam reforming and $\mathrm{CO}_{2}$ dry reforming of methane. The difference in thermal impregnation temperatures does not lead to any change in the crystalline phases, but leads to changes in crystallite size. Higher preparation temperature allows for stronger interaction between olivine and the active phase, which may suppress the coke formation. The difference of olivine geographical locations also leads to differences in catalyst characteristics, therefore affecting catalytic behavior. The amount of reducible $\mathrm{Fe}$ and Ni species and the surface Mg plays a role in determining catalyst activity and stability. Reaction studies on real tar for biomass gasification are needed to further establish the viability of these catalysts for bio-mass gasification.

\section{Acknowledgments}

The authors sincerely acknowledge financial support from the United States Department of Energy (DOE) through the cooperative agreement DE-FG36-04G014314.

\section{References}

[1] L. Devi, K.J. Ptasinski, F.J.J.G. Jansen, Biomass Bioenergy 24 (2003) 125.

[2] G.W. Huber, S. Iborra, A. Corma, Chem. Rev. 106 (2006) 4044.

[3] D. Sutton, B. Kelleher, J.R.H. Ross, Fuel Process. Technol. 73 (2001) 155.

[4] L. Garcia, M.L. Salvador, J. Arauzo, R. Bilbao, Energy Fuels 13 (1999) 
851.

[5] S. Rapagna, N. Jand, P.U. Foscolo, Int. J. Hydrogen Energy 23 (1998) 551.

[6] Li, C. and K. Suzuki, Renewable and Sustainable Energy Reviews,13(3) (2009) 594.

[7] Z. Abu El-Rub, E. A. Bramer, G. Brem, Ind. Eng. Chem. Res.43 (2004) 6911.

[8] L. Devi, M. Craje, P. Thüne, K. J. Ptasinski, F. J. J. G. Janssen, Appl. Catal. A: Gen. 294 (2005) 68.

[9] K. Polychronopoulou, A. Bakandritsos, V. Tzitzios, J.L.G. Fierro, A.M. Efstathiou, J. Catal. 241 (2006) 132.

[10] A. V. Bridgwater, Appl. Catal. A: Gen. 116 (1994) 5.

[11] D. Sutton, B. Kelleher, J. R. H. Ross, Fuel Process. Technol. 73 (2001) 155.

[12] J. Corella, M. A. Caballero, M. P. Aznar, C. Brage, Ind. Eng. Chem. Res. 42 (2003) 3001.

[13] L. Garcia, A. Benedicto, E. Romeo, M. L. Salvador, J. Arauzo, R. Bilbao, Energy \& Fuels 16 (2002) 1222.

[14] M. P. Aznar, M. A. Caballero, J. Gil, J. A. Martin, J. Corella, Ind. Eng. Chern. Res. 37 (1998) 2668.

[15] T. E. Solh, K. Jarosch, H. I. de Lasa, Applied Catal. A: Gen. 210 (2001) 315.

[16] T. Kimura, T. Miyazawa, T. Nishikawa, S. Kado, K. Okumura, T. Miyao, S.Naito, K. Kunimori, K. Tomishige, Appl. Catal. B: Environ. 68 (2006) 160.

[17] J. Srinakruang, K. Sato, T. Vitidsant, K. Fujimoto, Fuel 85 (2006) 2419.

[18] P.A. Simell, J.O. Hepola, A.O.I. Krause, Fuel 76 (1997) 1117.

[19] T. Furusawa, A. Tsutsumi, Appl. Catal., A 278 (2005) 207.

[20] P.A. Simell, E. Kurkela, P. Ståhlberg, J. Hepola, Catal. Today 27 (1996) 55.

[21] K. Tomishige, Y.G. Chen, K. Fujimoto, J. Catal. 181 (1999) 91.

[22] J. Corella, J.M. Toledo, M.P. Aznar, Ind. Eng. Chem. Res. 41 (2002) 3351.

[23] K.A. Magrini-Bair, S. Czernik, R. French, Y.O. Parent, E. Chornet, D.C.

Dayton, C. Feik, R. Bain, Appl. Catal. A: Gen. 318 (2007) 199.

[24] T. Keiichi, M. Tomohisa, K. Takeo, K. Koizumi, K. Naoto, Y. Muneyoshi, Appl. Catal. B: Environ. 60 (2005) 299.

[25] T. Wang, J. Chang, P. Lu, J. Zhu, Energy \& Fuels 19 (1) (2005) 22.

[26] D. Świerczyńskii, S. Libs, C. Courson, A. Kiennemann, Appl. Catal. B: Environ. 74 (2007) 211.

[27] C. Courson, L. Udron, C. Petit, A. Kiennemann, Sci.Technol. Adv. Materials 3 (2002) 271.

[28] D. Świerczyński, C. Courson, L. Bedel, A. Kiennemann, S. Vilminot, Chem. Mater. 18 (2006) 897.

[29] C. Courson, E. Makaga, C. Petit, A. Kiennemann, Catal. Today 63 (2000) 427.

[30] C. Courson, L. Udron, D. Swierczynski, C. Petit, A. Kiennemann, Catal. 
Today 76 (2002) 75.

[31] J. Corella, J. M. Toledo, R. Padilla, Energy Fuels 18 (2004) 713

[32] Z. Zhao, J.N. Kuhn, L.G. Felix, R.B. Slimane, C.W. Choi, U.S. Ozkan, Ind. Eng. Chem. Res. 47 (2008) 717.

[33] J.N. Kuhn, Z. Zhao, Senefeld-Naber, A., L.G. Felix, R.B. Slimane, C.W. Choi, U.S. Ozkan, Applied Catalysis A 341 (2008) 43.

[34] J.N. Kuhn, Z. Zhao, , L.G. Felix, R.B. Slimane, C.W. Choi, U.S. Ozkan, Applied Catalysis B 81(2008) 14.

[35] K.E. Kuebler, B.L. Jolliff, A. Wang, L.A. Haskin, Geochimica et Cosmochimica Acta 70 (2006) 6201.

[36] C.C. Lin, Phys. Chem. Minerals 28 (2001) 249.

[37] D. Świerczyński, C. Courson, J. Guille, A. Kiennemann, J. Phys. IV. 118 (2004) 385.

[38] D. Świerczyński, C. Courson, L. Bedel, A. Kiennemann, J. Guille, Chem. Mater. 18 (2006) 4025. 


\section{List of Tables and Figures}

Table 1. Relative amounts of $\mathrm{Ni}, \mathrm{Fe}, \mathrm{Si}$ and $\mathrm{Mg}$ species on the surface of olivine supported $\mathrm{Ni}_{2} \mathrm{SiO}_{4}$ catalysts prepared at different thermal impregnation temperatures

Table 2. Relative amounts of $\mathrm{Ni}$, Fe and $\mathrm{Mg}$ species on the surface of various olivines supported $\mathrm{Ni}_{2} \mathrm{SiO}_{4}$ catalysts

Figure 1. X-ray diffraction patterns of olivine with and without $\mathrm{Ni}_{2} \mathrm{SiO}_{4}\left(\mathrm{Ni}_{2} \mathrm{SiO}_{4}\right.$ is included as reference). $\mathrm{Ni}_{2} \mathrm{SiO}_{4}, \bigcirc \mathrm{Mg}_{2} \mathrm{SiO}_{4}, \nabla \mathrm{y}-\mathrm{Fe}_{2} \mathrm{O}_{3}, \boldsymbol{\Delta} \mathrm{Fe}_{3} \mathrm{O}_{4}$. (Thermal impregnation at $1100^{\circ} \mathrm{C}$ )

Figure 2. Laser Raman spectra of olivine with and without $\mathrm{Ni}_{2} \mathrm{SiO}_{4}\left(\mathrm{Ni}_{2} \mathrm{SiO}_{4}\right.$ is included as reference). (Thermal impregnation at $1100^{\circ} \mathrm{C}$ ).

Figure 3. TPR profiles of olivine with and without $\mathrm{Ni}_{2} \mathrm{SiO}_{4}\left(\mathrm{Ni}_{2} \mathrm{SiO}_{4}\right.$ is included as reference). (Thermal impregnation at $1100^{\circ} \mathrm{C}$ ).

Figure 4. TPRxn profiles (a) methane signal, b) hydrogen signal over olivine with and without $\mathrm{Ni}_{2} \mathrm{SiO}_{4}\left(\mathrm{Ni}_{2} \mathrm{SiO}_{4}\right.$ is included as reference). (Thermal impregnation at $1100^{\circ} \mathrm{C}$ ).

Figure 5. X-ray diffraction patterns of olivine supported $\mathrm{Ni}_{2} \mathrm{SiO}_{4}$ prepared using different thermal impregnation temperatures. $\mathrm{Ni}_{2} \mathrm{SiO}_{4}, \Delta \mathrm{Mg}_{2} \mathrm{SiO}_{4}$, $\square$ $\mathrm{Y}-\mathrm{Fe}_{2} \mathrm{O}_{3}, \bigcirc \mathrm{Fe}_{3} \mathrm{O}_{4}$

Figure 6. Laser Raman spectra of olivine supported $\mathrm{Ni}_{2} \mathrm{SiO}_{4}$ prepared at different thermal impregnation temperatures.

Figure 7. TPR profiles of olivine supported $\mathrm{Ni}_{2} \mathrm{SiO}_{4}$ prepared at different thermal impregnation temperatures.

Figure 8. X-ray photoelectron spectra of olivine supported $\mathrm{Ni}_{2} \mathrm{SiO}_{4}$ prepared at different thermal impregnation temperatures.

Figure 9. (a) and (b) TPRxn profiles, (c) TPO profiles over olivine supported $\mathrm{Ni}_{2} \mathrm{SiO}_{4}$ prepared atdifferent thermal impregnation temperatures. 
Figure 10. X-ray diffraction patterns of the supported $\mathrm{Ni}_{2} \mathrm{SiO}_{4}$ catalyst on olivines obtained from different locations. (Thermal treatment at $1100^{\circ} \mathrm{C}$ ).

Figure 11. Laser Raman spectra of the supported $\mathrm{Ni}_{2} \mathrm{SiO}_{4}$ catalyst on olivines obtained from different locations. (Thermal treatment at $1100^{\circ} \mathrm{C}$ ).

Figure 12. TPR profiles of the supported $\mathrm{Ni}_{2} \mathrm{SiO}_{4}$ catalyst on olivines obtained from different locations. (Thermal treatment at $1100^{\circ} \mathrm{C}$ ).

Figure 13. X-ray photoelectron spectra of the supported $\mathrm{Ni}_{2} \mathrm{SiO}_{4}$ catalyst on olivines obtained from different locations. (Thermal treatment at $1100^{\circ} \mathrm{C}$ )

Figure 14. (a) and (b) TPRxn profiles, (c) TPO profiles on olivine supported $\mathrm{Ni}_{2} \mathrm{SiO}_{4}$ catalyst prepared via thermal impregnation at $1100^{\circ} \mathrm{C}$.

Figure 15. Experiments to probe the possible reactions in simulated biomass gasification on olivine-supported $\mathrm{Ni}_{2} \mathrm{SiO}_{4}$ catalyst prepared via thermal impregnation at $1100^{\circ} \mathrm{C}$ : (a) $\mathrm{CO}_{2}+\mathrm{CH}_{4},(\boldsymbol{b}) \mathrm{CO}_{2}+\mathrm{H}_{2}$, (c) $\mathrm{CO}+\mathrm{H}_{2}$, (d) $\mathrm{CO}+$ $\mathrm{H}_{2} \mathrm{O}$.

Figure 16. Experiments to probe the possible reactions in simulated biomass gasification over bare Norwegian olivine: (a) $\mathrm{CO}_{2}+\mathrm{CH}_{4},(\boldsymbol{b}) \mathrm{CO}_{2}+\mathrm{H}_{2}$, (c) $\mathrm{CO}$ $+\mathrm{H}_{2},(\boldsymbol{d}) \mathrm{CO}+\mathrm{H}_{2} \mathrm{O}$. 
Table 1. Relative amounts of $\mathrm{Ni}, \mathrm{Fe}, \mathrm{Si}$ and $\mathrm{Mg}$ species on the surface of olivine supported $\mathrm{Ni}_{2} \mathrm{SiO}_{4}$ catalysts prepared at different thermal impregnation temperatures

\begin{tabular}{lcccl}
\hline Catalyst & $A_{\text {Ni } 2 \mathrm{p}} / A_{\text {total }}$ & $A_{\text {Fe } 2 \mathrm{p}} / A_{\text {total }}$ & $A_{\mathrm{Mg} 2 \mathrm{p}} / A_{\text {total }}$ & $A_{\mathrm{Si} 2 \mathrm{p}} / A_{\text {total }}$ \\
\hline TI-1300 & 0.1703 & 0.0653 & 0.3038 & 0.4606 \\
Tl-1100 & 0.1327 & 0.0963 & 0.2009 & 0.5701 \\
\hline \multicolumn{5}{c}{$A_{\text {total }}=A_{\text {Fe } 2 \mathrm{p}}+A_{\mathrm{Ni} 2 \mathrm{p}}+A_{\mathrm{Si} 2 \mathrm{p}}+A_{\mathrm{Mg} 2 \mathrm{p}}$}
\end{tabular}


Table 2. Relative amounts of $\mathrm{Ni}, \mathrm{Fe}$ and $\mathrm{Mg}$ species on the surface of various $\mathrm{Ni}_{2} \mathrm{SiO}_{4}$ catalysts supported on different olivine samples

\begin{tabular}{|l|l|l|l|l|}
\hline Catalyst & $A_{\mathrm{Ni} 2 \mathrm{p}} / A_{\text {total }}$ & $A_{\text {Fe 2p }} / A_{\text {total }}$ & $A_{\mathrm{Mg} 2 \mathrm{p}} / A_{\text {total }}$ & $A_{\mathrm{Si} 2 \mathrm{p}} / A_{\text {total }}$ \\
\hline $\mathrm{Ni}_{2} \mathrm{SiO}_{4} / \mathrm{NC}$ & 0.0953 & 0.0932 & 0.2849 & 0.5265 \\
\hline $\mathrm{Ni}_{2} \mathrm{SiO}_{4} / \mathrm{NOR}$ & 0.1327 & 0.0963 & 0.2009 & 0.5701 \\
\hline
\end{tabular}

$$
A_{\text {total }}=A_{\mathrm{Fe} 2 \mathrm{p}}+A_{\mathrm{Ni} 2 \mathrm{p}}+A_{\mathrm{Si} 2 \mathrm{p}}+A_{\mathrm{Mg} 2 \mathrm{p}}
$$




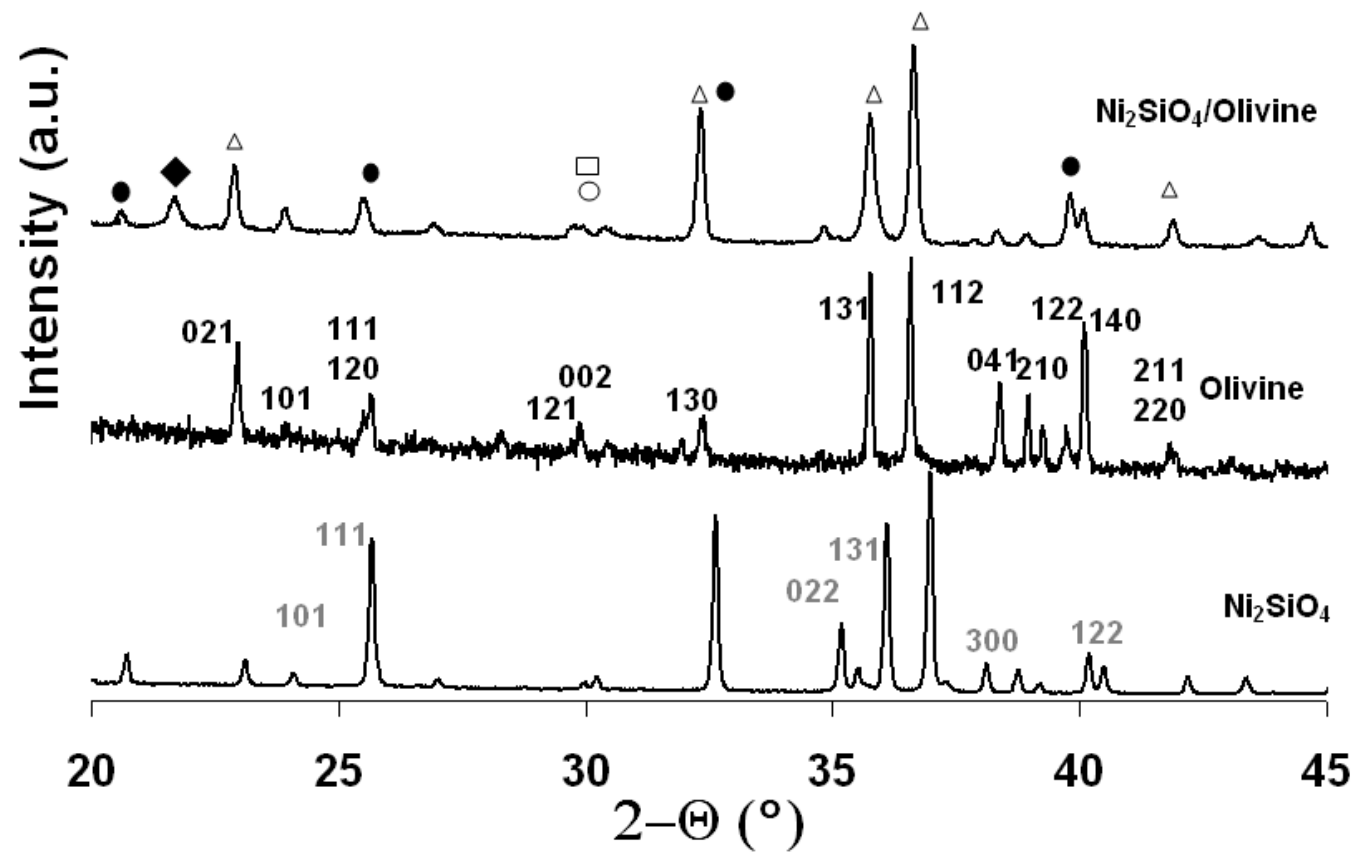

Figure 1. X-ray diffraction patterns of olivine with and without $\mathrm{Ni}_{2} \mathrm{SiO}_{4}\left(\mathrm{Ni}_{2} \mathrm{SiO}_{4}\right.$ is included as reference). - $\mathrm{Ni}_{2} \mathrm{SiO}_{4}, \Delta \mathrm{Mg}_{2} \mathrm{SiO}_{4, \square} \mathrm{y}-\mathrm{Fe}_{2} \mathrm{O}_{3}, \bigcirc \mathrm{Fe}_{3} \mathrm{O}_{4}$. (Thermal impregnation at $\left.1100^{\circ} \mathrm{C}\right)$ 


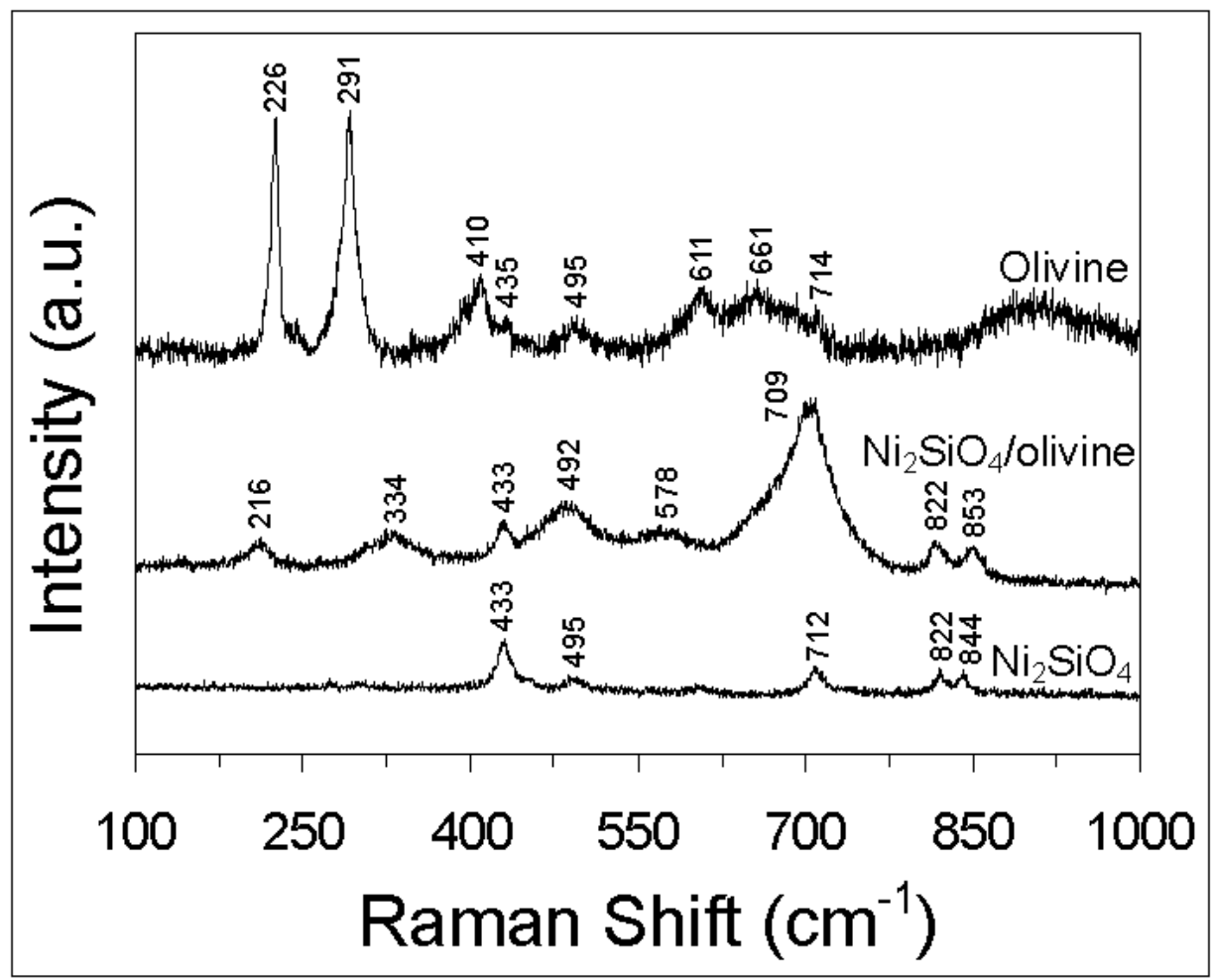

Figure 2. Laser Raman spectra of olivine with and without $\mathrm{Ni}_{2} \mathrm{SiO}_{4}\left(\mathrm{Ni}_{2} \mathrm{SiO}_{4}\right.$ is included as reference) (Thermal impregnation at $1100^{\circ} \mathrm{C}$ ). 


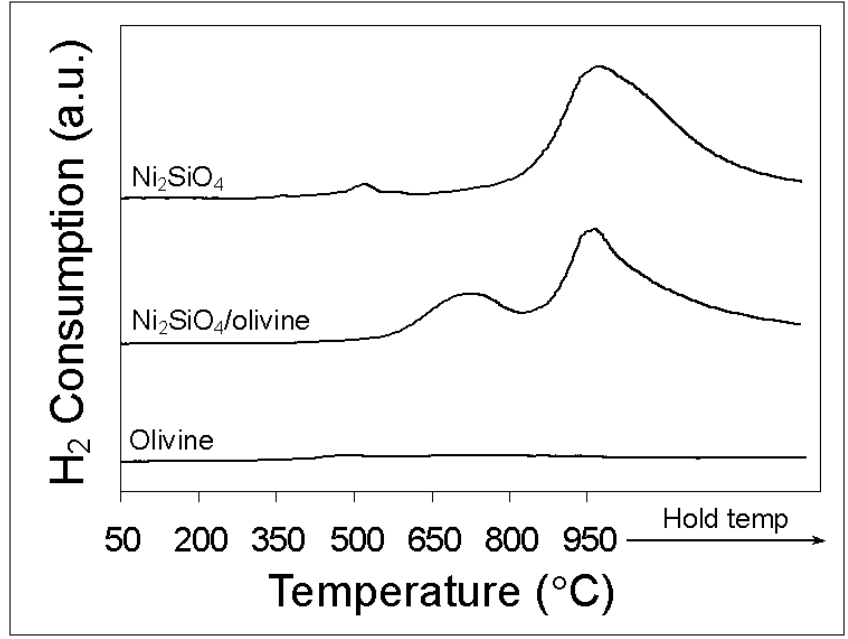

Figure 3. TPR profiles of olivine with and without $\mathrm{Ni}_{2} \mathrm{SiO}_{4}\left(\mathrm{Ni}_{2} \mathrm{SiO}_{4}\right.$ is included as reference). (Thermal impregnation at 1100.C) 
a)

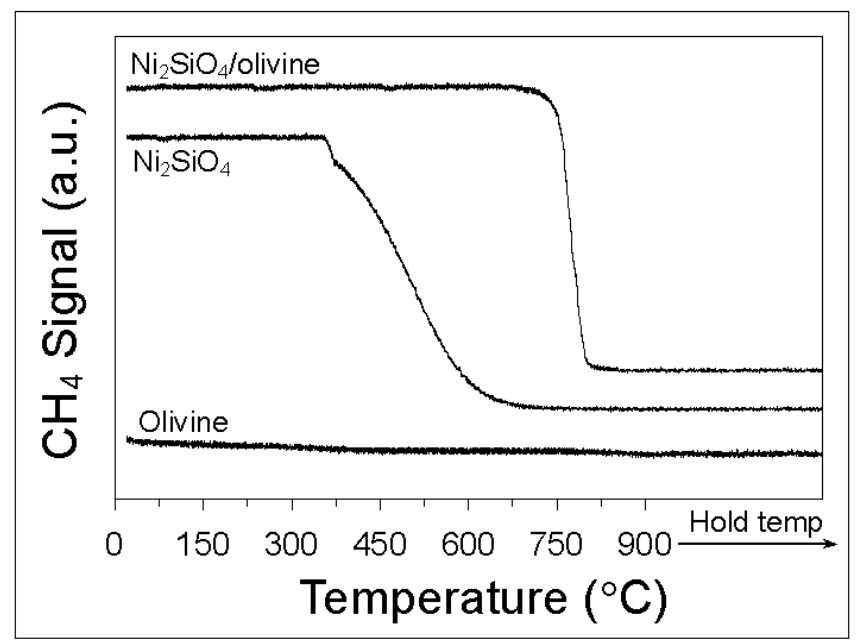

b)

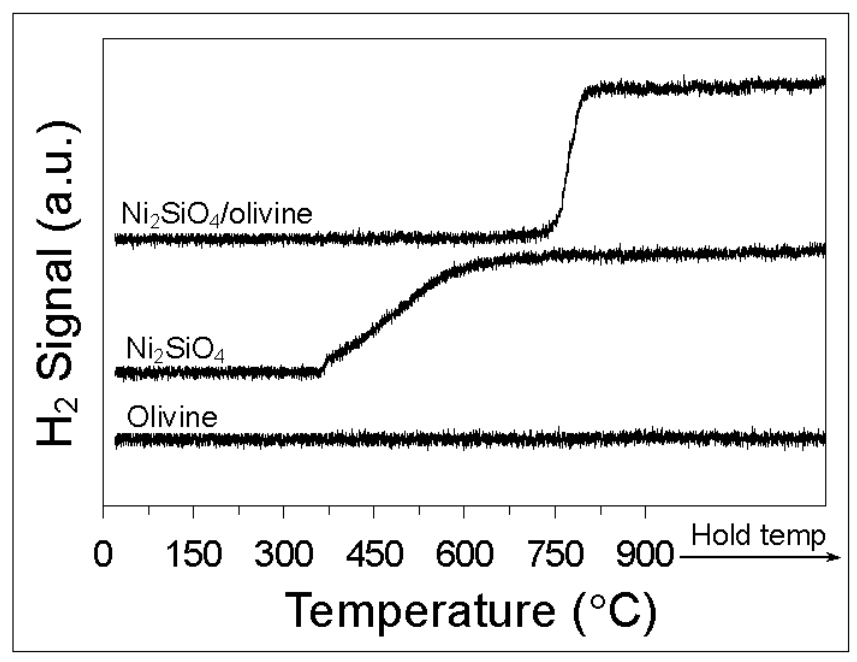

Figure 4. TPRxn profiles (a) methane signal, b) hydrogen signal over olivine with and without $\mathrm{Ni}_{2} \mathrm{SiO}_{4}\left(\mathrm{Ni}_{2} \mathrm{SiO}_{4}\right.$ is included as reference). (Thermal impregnation at $1100^{\circ} \mathrm{C}$ ) 


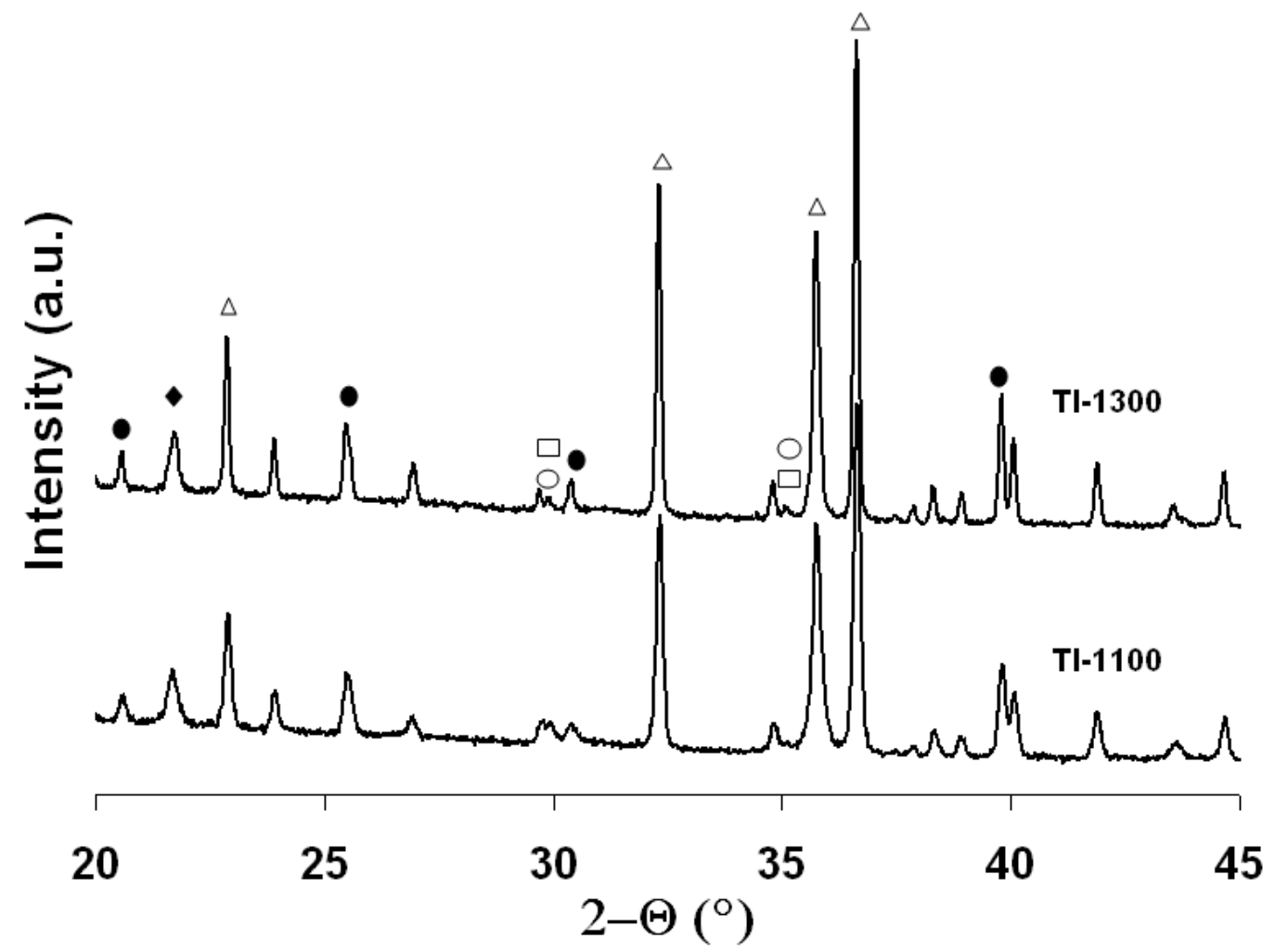

Figure 5. X-ray diffraction patterns of olivine supported $\mathrm{Ni}_{2} \mathrm{SiO}_{4}$ prepared using different thermal impregnation temperatures. $-\mathrm{Ni}_{2} \mathrm{SiO}_{4}, \Delta \mathrm{Mg}_{2} \mathrm{SiO}_{4}, \square \mathrm{y}-\mathrm{Fe}_{2} \mathrm{O}_{3}, \bigcirc \mathrm{Fe}_{3} \mathrm{O}_{4}$ 


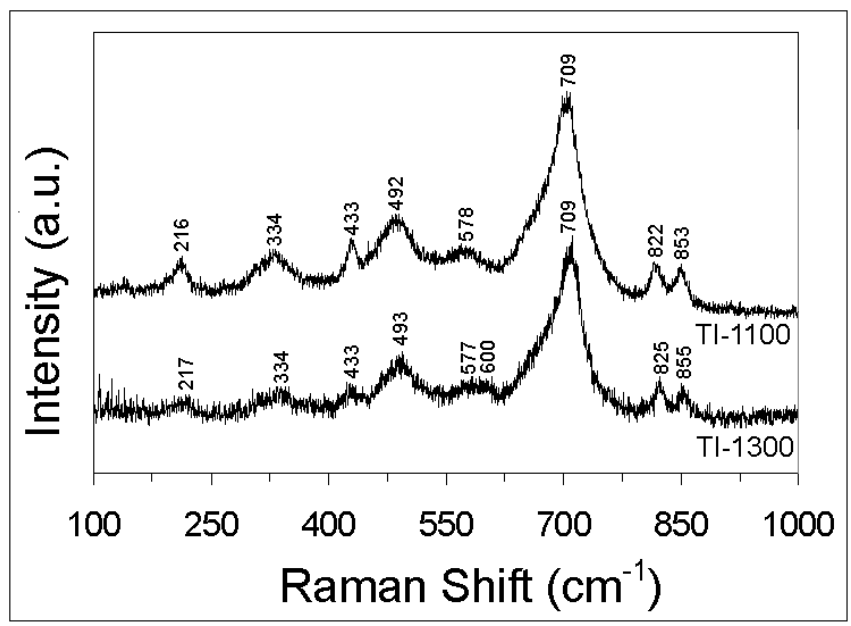

Figure 6. Laser Raman spectra of olivine supported $\mathrm{Ni}_{2} \mathrm{SiO}_{4}$ prepared at different thermal impregnation temperatures. 


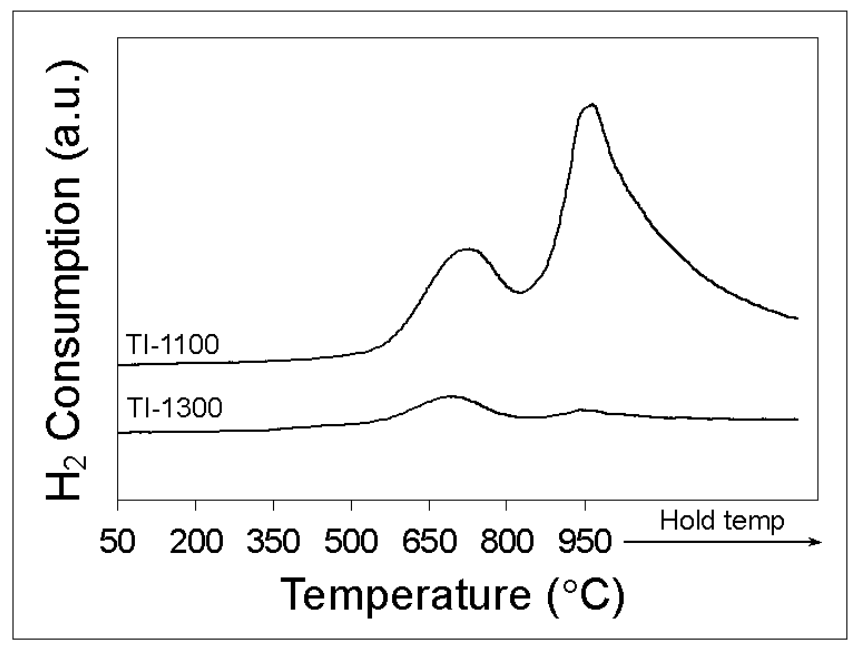

Figure 7. TPR profiles of olivine supported $\mathrm{Ni}_{2} \mathrm{SiO}_{4}$ prepared at different thermal impregnation temperatures. 

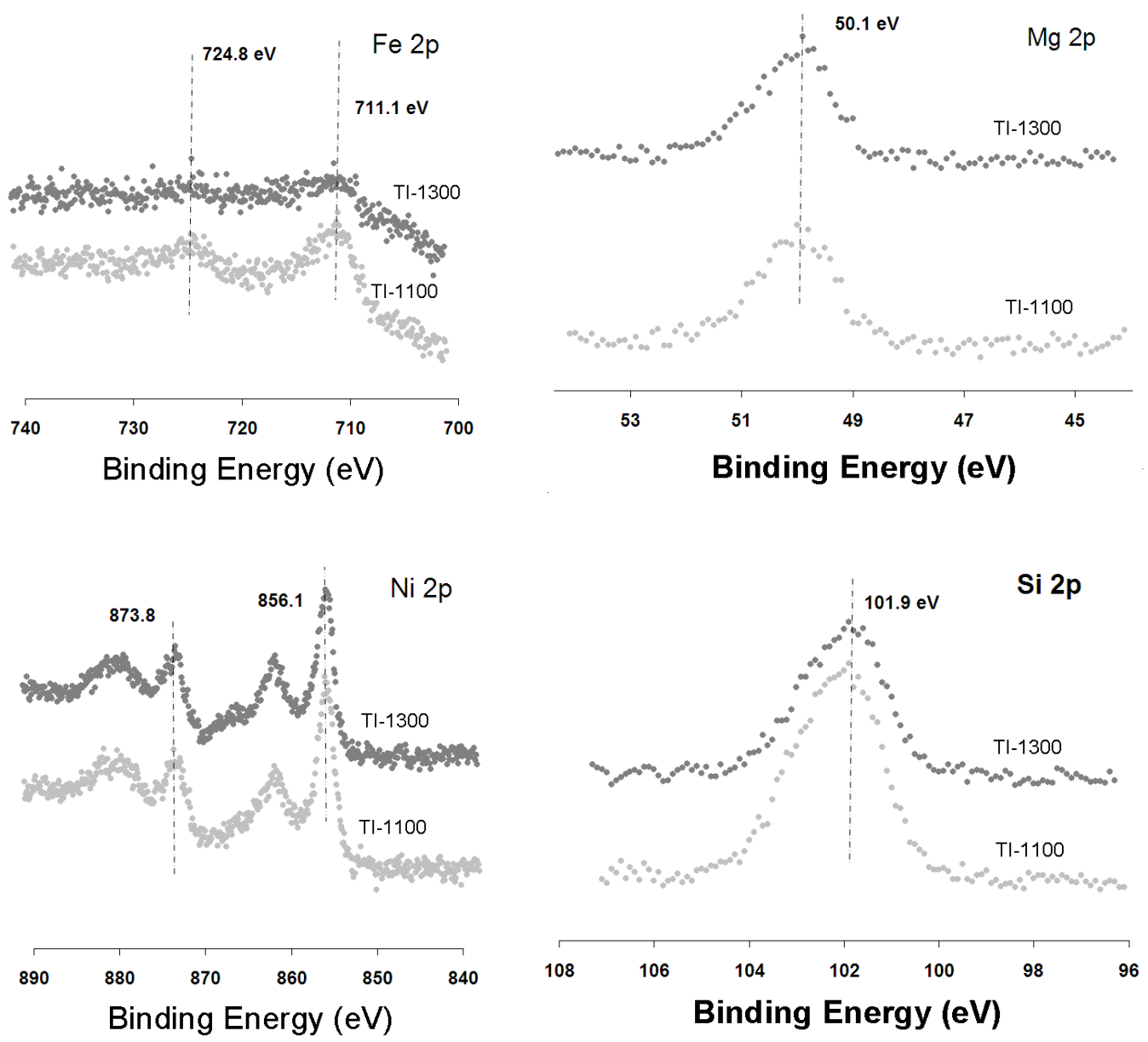

Figure 8. X-ray photoelectron spectra of olivine supported $\mathrm{Ni}_{2} \mathrm{SiO}_{4}$ prepared at different thermal impregnation temperatures. 
a)

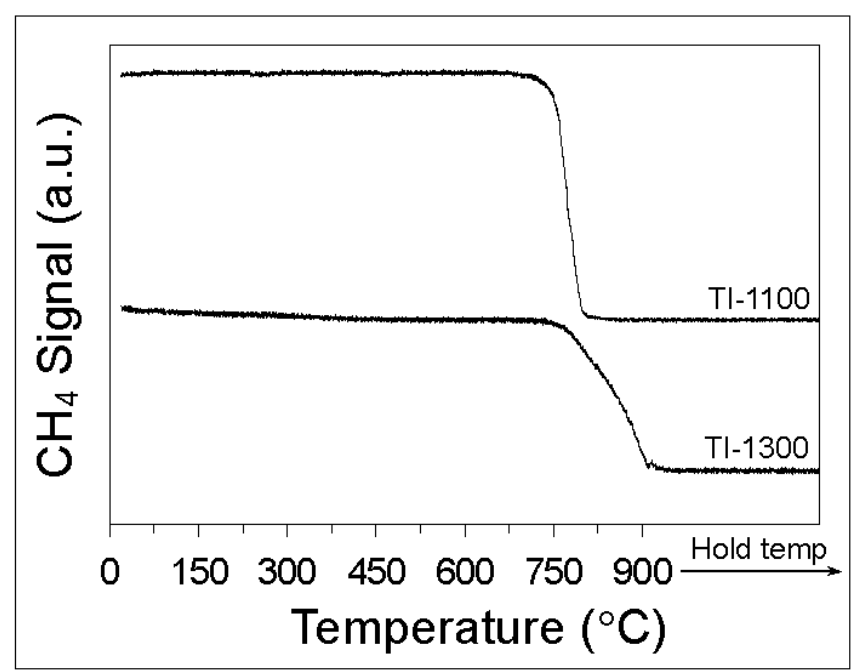

b)

c)
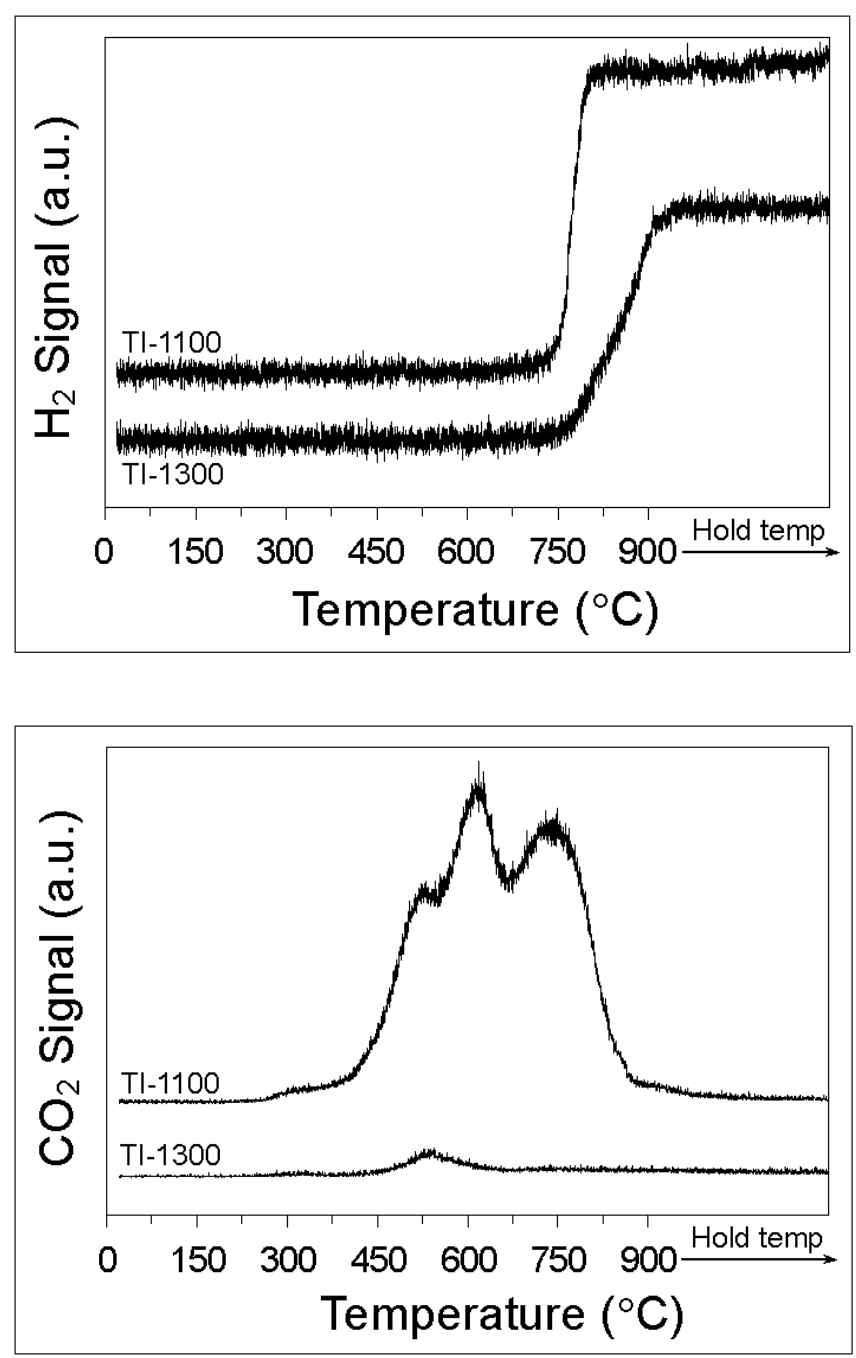

Figure 9. (a) and (b) TPRxn profiles, (c) TPO profiles over olivine supported $\mathrm{Ni}_{2} \mathrm{SiO}_{4}$ prepared at different thermal impregnation temperatures. 


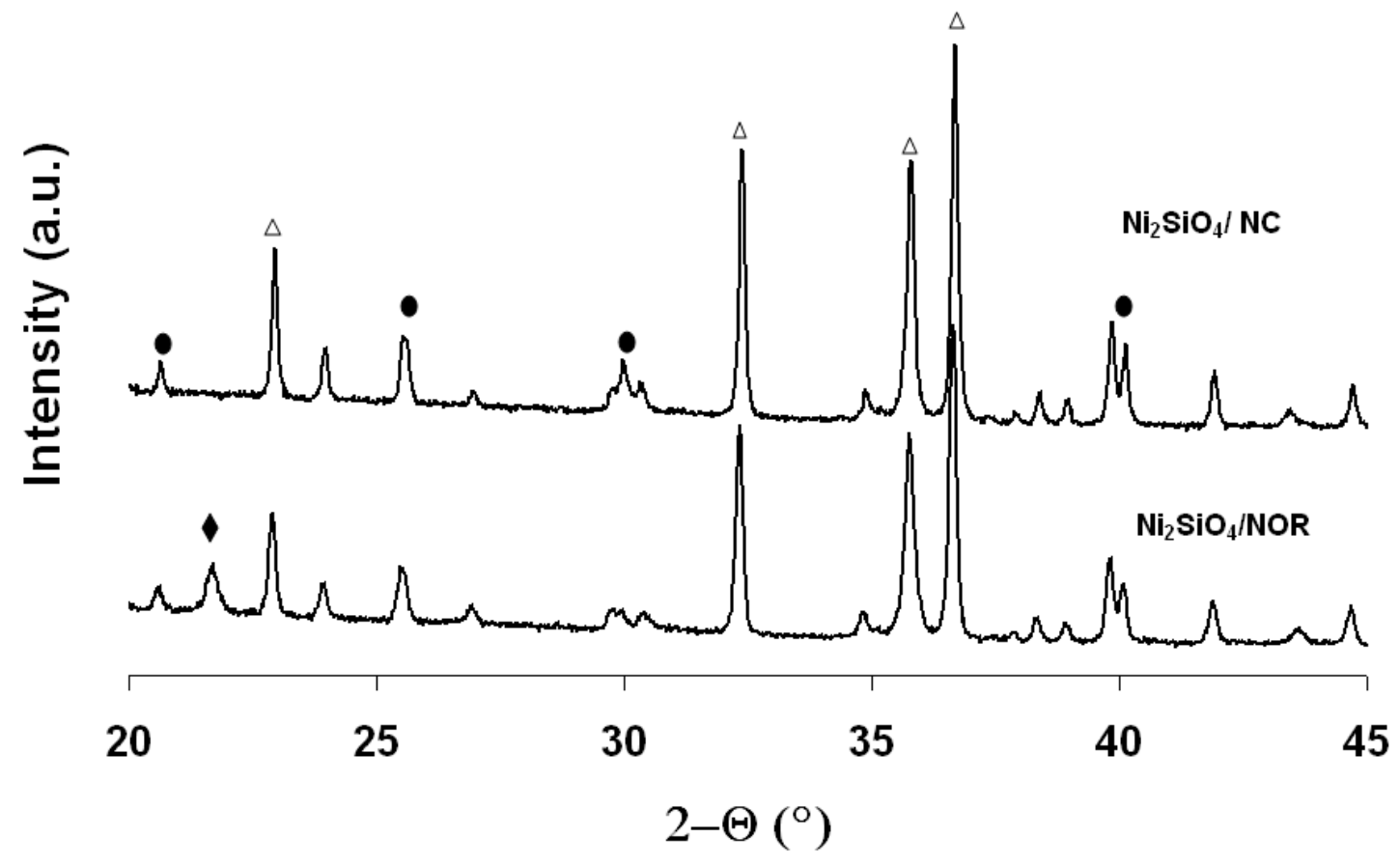

Figure 10. X-ray diffraction patterns of the supported $\mathrm{Ni}_{2} \mathrm{SiO}_{4}$ catalyst on olivines obtained from different locations. (Thermal treatment at $1100^{\circ} \mathrm{C}$ ) 


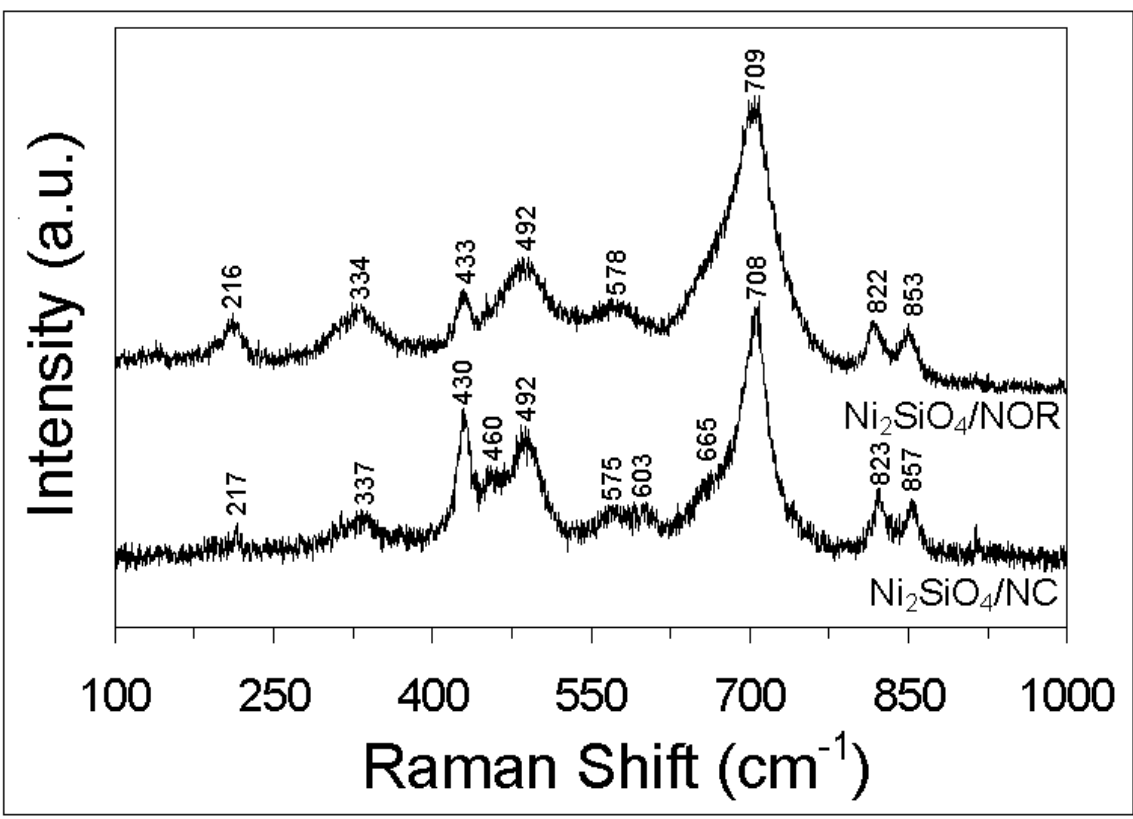

Figure 11. Laser Raman spectra of the supported $\mathrm{Ni}_{2} \mathrm{SiO}_{4}$ catalyst on olivines obtained from different locations. (Thermal treatment at $1100^{\circ} \mathrm{C}$ ) 


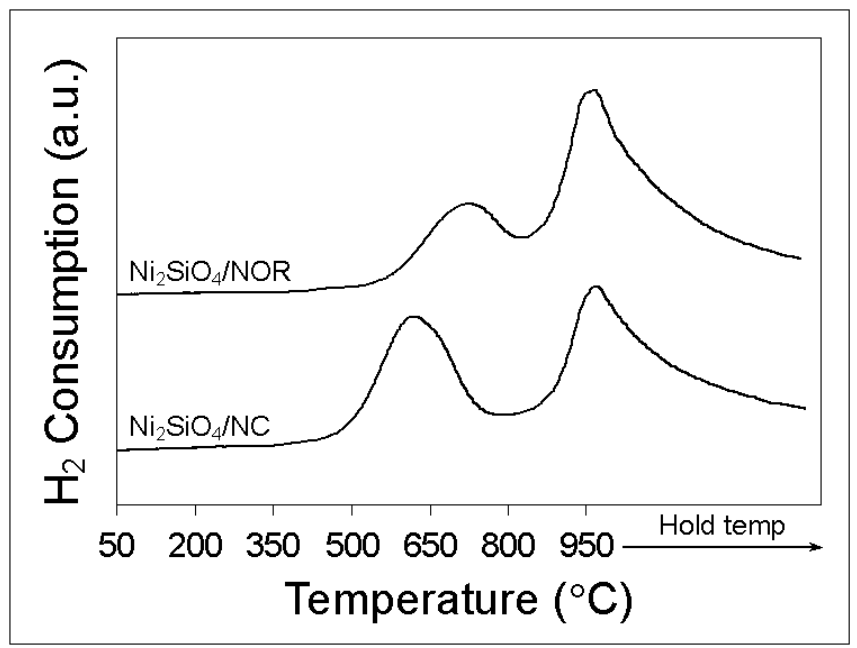

Figure 12. TPR profiles of the supported $\mathrm{Ni}_{2} \mathrm{SiO}_{4}$ catalyst on olivines obtained from different locations. (Thermal treatment at $1100^{\circ} \mathrm{C}$ ) 

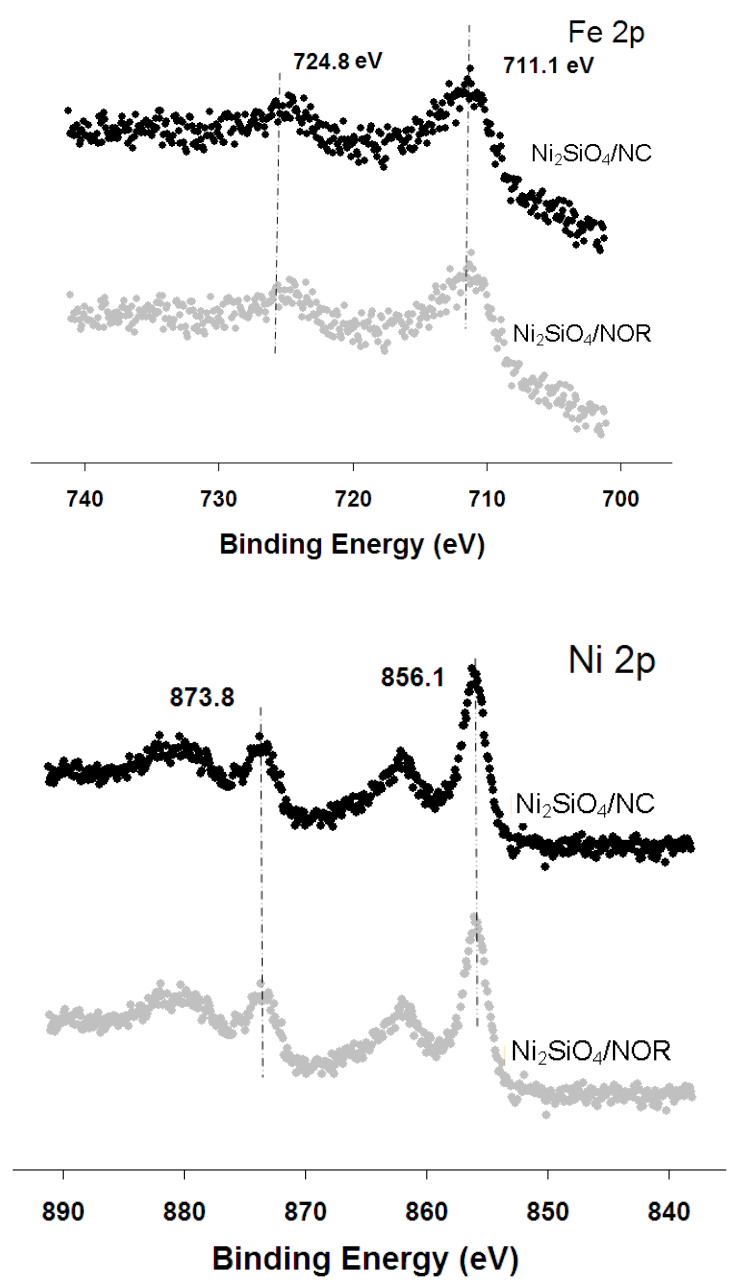

$\operatorname{Mg} 2 p$

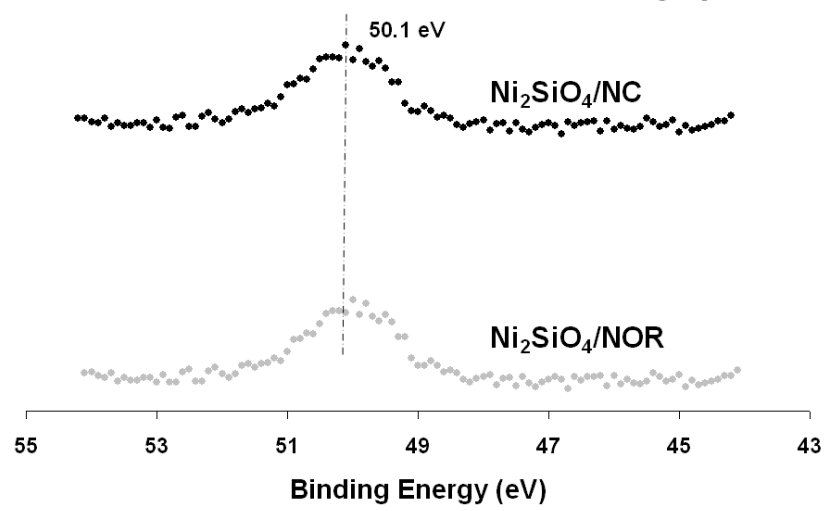

Figure 13. X-ray photoelectron spectra of the supported $\mathrm{Ni}_{2} \mathrm{SiO}_{4}$ catalyst on olivines obtained from different locations. (Thermal treatment at $1100^{\circ} \mathrm{C}$ ) 
a)

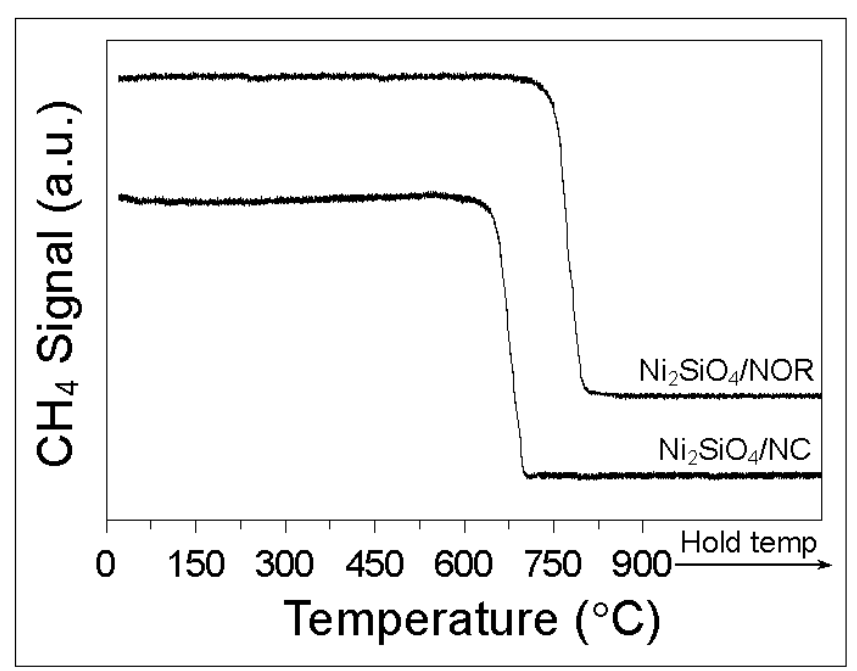

b)

c)
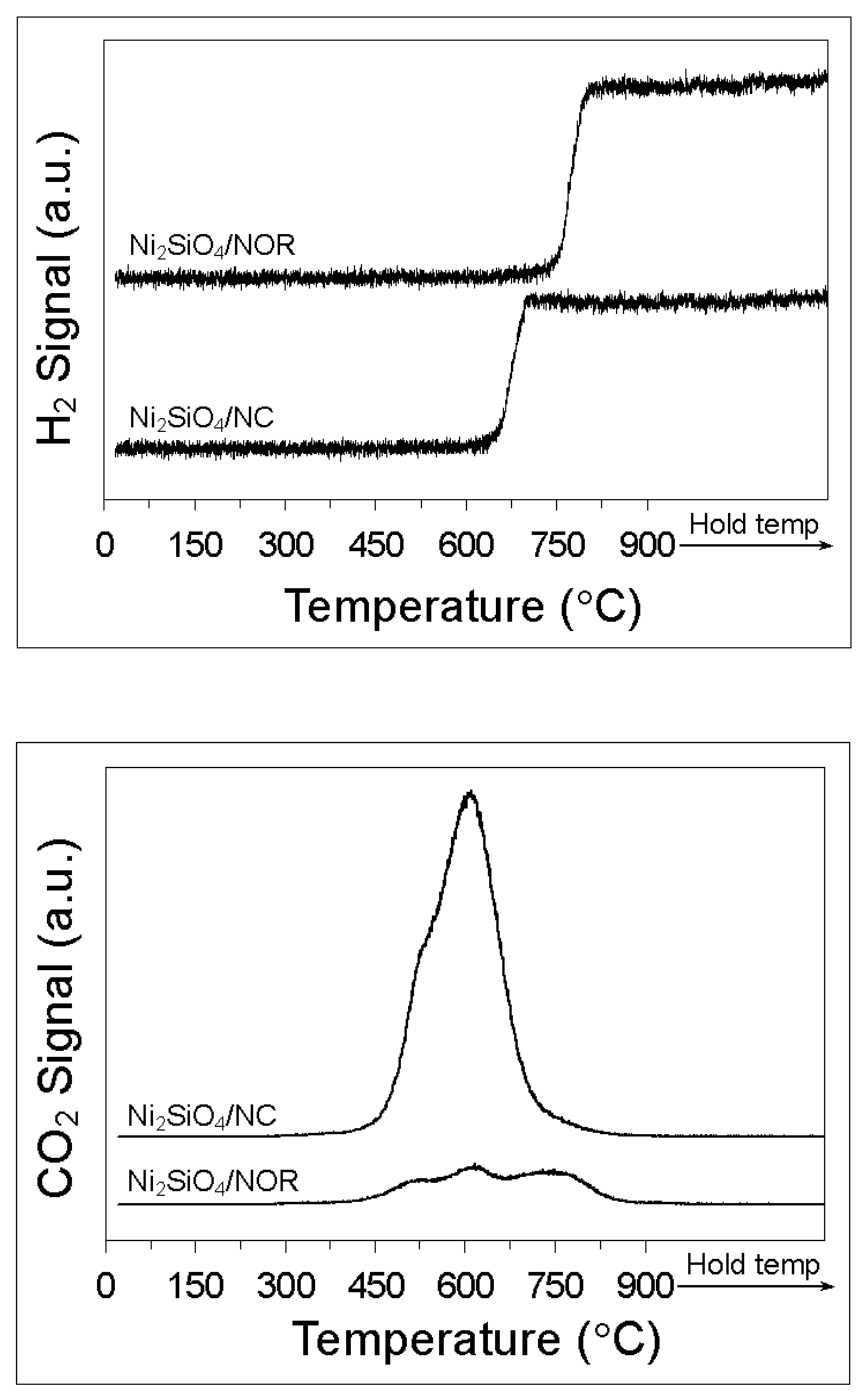

Figure 14. (a) and (b) TPRxn profiles, (c) TPO profiles on olivine supported $\mathrm{Ni}_{2} \mathrm{SiO}_{4}$ catalyst prepared via thermal impregnation at $1100^{\circ} \mathrm{C}$. 

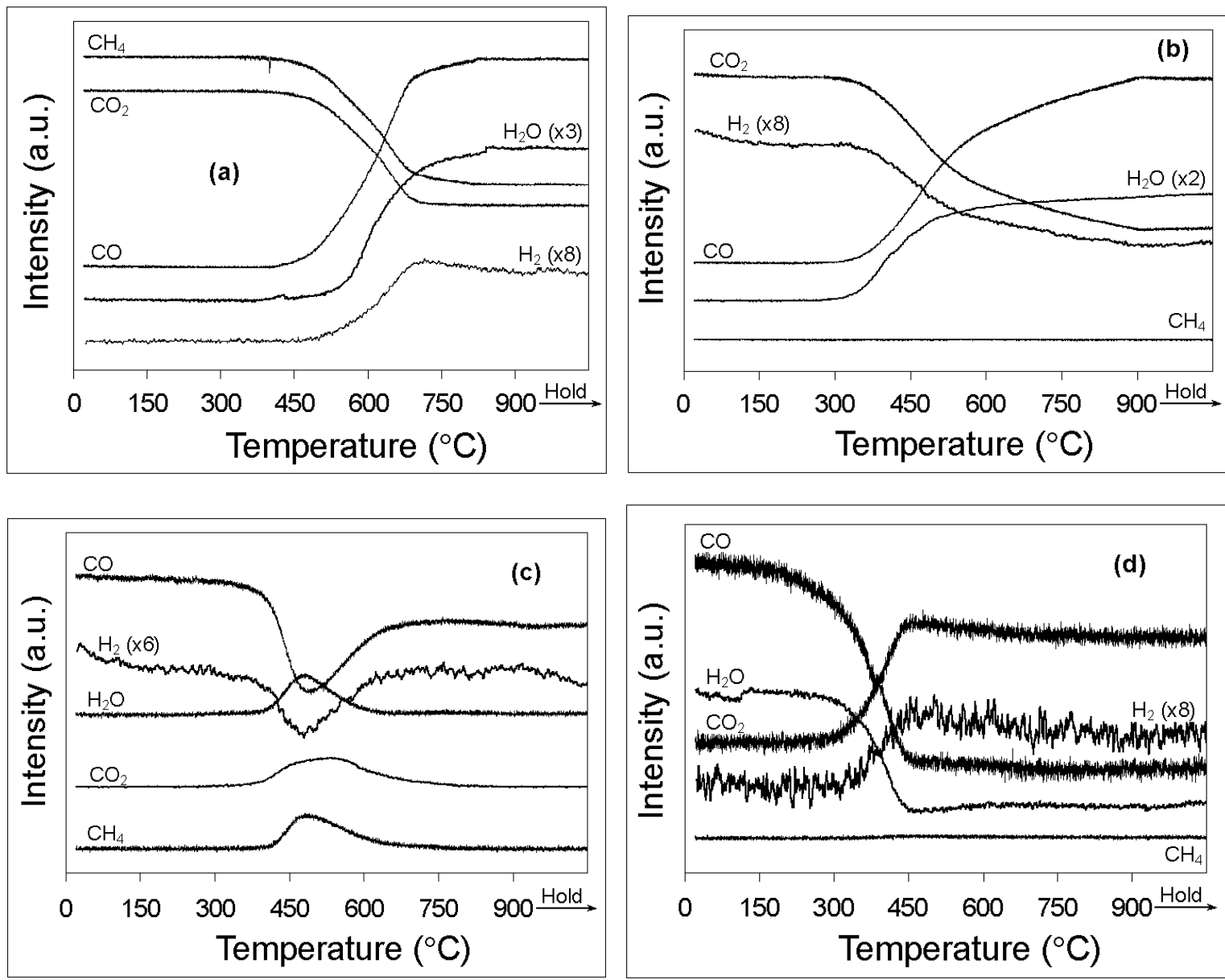

Figure 15. Experiments to probe the possible reactions in simulated biomass gasification on olivine-supported $\mathrm{Ni}_{2} \mathrm{SiO}_{4}$ catalyst prepared via thermal impregnation at $1100^{\circ} \mathrm{C}$ : (a) $\mathrm{CO}_{2}+\mathrm{CH}_{4},(\boldsymbol{b}) \mathrm{CO}_{2}+\mathrm{H}_{2}$, (c) $\mathrm{CO}+\mathrm{H}_{2}$, (d) $\mathrm{CO}+\mathrm{H}_{2} \mathrm{O}$. 

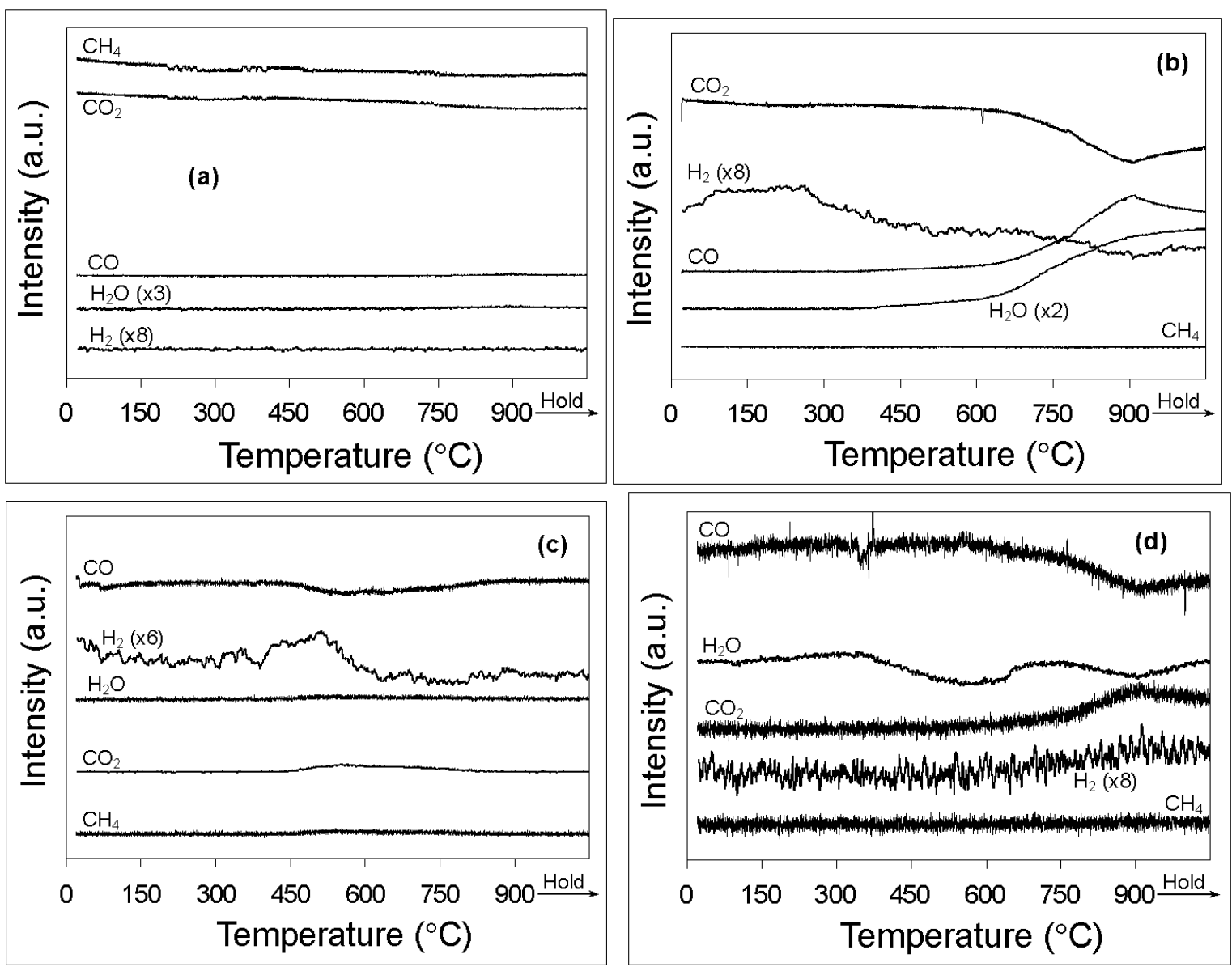

Figure16. Experiments to probe the possible reactions in simulated biomass gasification over bare Norwegian olivine: (a) $\mathrm{CO}_{2}+\mathrm{CH}_{4}$, (b) $\mathrm{CO}_{2}+\mathrm{H}_{2}$, (c) $\mathrm{CO}+\mathrm{H}_{2}$, (d) $\mathrm{CO}+\mathrm{H}_{2} \mathrm{O}$. 